\title{
Food Craving
}

National Cancer Institute

\section{Source}

National Cancer Institute. Food Craving. NCI Thesaurus. Code C92801.

An abnormal desire for eating certain foods. 